\title{
Impact of Crude Oil on Soil Nitrogen Dynamics and Uptake by Legumes Grown in Wetland Ultisol of the Niger Delta, Nigeria
}

\author{
Richard C. John*, Emem S. Ntino, Alfred Y. Itah \\ Department of Microbiology, University of Uyo, Uyo, Nigeria \\ Email: "richritom7@yahoo.com
}

Received 23 January 2016; accepted 13 March 2016; published 17 March 2016

Copyright (C) 2016 by authors and Scientific Research Publishing Inc.

This work is licensed under the Creative Commons Attribution International License (CC BY). http://creativecommons.org/licenses/by/4.0/

(c) (7) Open Access

\begin{abstract}
The effects of crude oil on soil nitrogen dynamics and cycling in plant-soil ecosystems and its effect on the growth of legumes (Calopogonium mucunoides, Centrosema pubescens and Pueraria phaseolodes) grown in wetland ultisols were investigated. The test plants species were grown on wetland soil simulated with $0.35,10.8,20.5$, and $50 \mathrm{~g} \cdot \mathrm{kg}^{-1}$ levels of crude oil contamination. The results showed time and species dependent variation in mineral $\mathrm{N}$ content of the treated soils. The variation is indicative of significant interaction between the hydrocarbon content and plant species. Variations in microbial $\mathrm{N}$ and microbial $\mathrm{C}$ were similar and correlation between the microbial $\mathrm{N}$ and the total $\mathrm{C}$ (Organic matter (C) + hydrocarbon content $(\mathrm{C})$ ) in soil was highly significant $(\mathrm{r}=$ $0.96, n=12, P \leq 0.01)$. The presence of hydrocarbon contaminant widens the $C: N$ ratio in soil and leads to more available $\mathrm{N}$ being immobilized by soil microorganisms, which reduces available $\mathrm{N}$ for plant uptake. This result implies that crude oil contamination significantly reduces $\mathrm{N}$ uptake by plants but increases $\mathrm{N}$ accumulation in soil microbial biomass. The findings show that $\mathrm{N}$ dynamics, transformation and cycling in soil are influenced by hydrocarbons and that the interactions between hydrocarbon content and plant species in contaminated soil are remarkable. The use of plant Centrosema pubescens with poultry manure or NPK fertilizer for bioremediation is more effective than that of Calopogonium mucunoides and Pueraria phaseoloides. However, the selective attributes of the various treatment approaches adopted here may be exploited for enhanced remediation of contaminated wetlands in the Niger Delta region of Nigeria.
\end{abstract}

\section{Keywords}

Impact, Crude Oil, Soil Nitrogen Dynamics, Legumes, Wetland Ultisol, Niger Delta

\footnotetext{
${ }^{*}$ Corresponding author.
}

How to cite this paper: John, R.C., Ntino, E.S. and Itah, A.Y. (2016) Impact of Crude Oil on Soil Nitrogen Dynamics and Uptake by Legumes Grown in Wetland Ultisol of the Niger Delta, Nigeria. Journal of Environmental Protection, 7, 507-515. http://dx.doi.org/10.4236/jep.2016.74046 


\section{Introduction}

The Niger Delta terrestrial and aquatic systems are generally the main recipients of crude oil spillages, sometimes resulting in large scale contamination of the environment. Oil spills in the last two decades have given rise to increased scientific knowledge of the behaviour of hydrocarbons and have led to the development of new intervention method [1]. Of the many remediation methods currently in use, bioremediation is viewed as one of the most promising technologies. The approach that has been exploited most consists of stimulation of the soil indigenous microflora by adding an electron acceptor and/or nutriments, especially nitrogen in the form of ammonium salts [2]-[4]. This nitrogen source is exploited mainly by microbial biomass for growth and production of pollutants-degrading enzymes.

Nitrogen dynamics and cycling play important roles in bioremediation and reclamation of hydrocarbon-contaminated soils, because nitrogen is an essential element for microbial activity and plant growth. Nitrogen dynamics and cycling in hydrocarbon-contaminated soils may differ from those in uncontaminated agricultural soils [5] because hydrocarbons can change soil physical, chemical and biological properties. In spite of all the harmful effects widely reported, [6] [7] have revealed improved growth of tropical legumes grown on soil contaminated with crude oil in wetland soil. [8] noted that organic matter of soils polluted with crude oil increased through the activities of nitrogen-fixing microorganisms. The nitrogen-fixing capacity of legumes stabilizes the soil nitrogen and organic carbon content in the rhizosphere than non-rhizosphere soils [9].

However, in experiment to measure the nitrogen accumulated by plants grown in solution culture and small field plots at Ibadan in Nigeria, [10] reported that cowpea (Vigna unguiculata), green grain (Vigna radiata) and calopo (Calopogonium mucunoides) can accumulate nitrogen at rates in excess of $300 \mathrm{~kg}$ within 12 - 14 weeks. In another survey of 15 oil-contaminated sites, [11] reported the dominance of leguminous plants among the surviving flora, indicating a selective advantage of plants with a symbiotic nitrogen fixing potential. Similarly, [12] showed that low level $(0.75 \%)$ of oil in soil improved the growth and nodule development of soya beans. This improvement could be attributed to nitrogen fixation or additional nutrients released from the activities of the tolerant organisms.

However, there is a paucity of information on the effect of hydrocarbons on nitrogen dynamics and cycling in plant-soil systems of wetlands during remediation. In this experiment, the different nitrogen forms in plant-soil systems containing uncontaminated soil, crude oil, contaminated soil and remediated soils covered with Calopo (Calopogonium mucunoides), Centro (Centrosema pubescens) and Pueraria (Pueraria phaseoloides) were examined.

\section{Materials and Methods}

\subsection{Source of Test Soil Samples}

The soil samples used in the study were collected from wetland soil sites, where there are no recorded cases of crude oil contamination. The soil was obtained within the vicinity of Ikot Obio Nko stream in Ibesikpo Asutan Local Government Area of Akwa Ibom State. Akwa Ibom State is located in the Niger Delta region of Nigeria. The area is characterized by sand and clay deposits. The top soil is characterized as sandy loam and is within a tropical rainforest zone. The soil is moist most of the year round due to excessive rainfall of about $2700 \mathrm{~mm}$. This volume of rainfall provides great amounts of surface run-off rivulets and occasional streams which may carry substances like crude oil to nearby lands and rivers. The prevalent species of legumes Calopogonium mucunoides, Centrosema pubescens and Pueraria phaseoloides (members of the family Leguminosae and subfamily Faboideae) found in the wetland sites were selected for the study.

\subsection{Contamination and Remediation of Test Soil}

Twenty litres of Bonny Light crude oil was poured on each of the ten plots with dimension $4 \times 4 \mathrm{ft}$. The objective was to simulate conditions of a major spill. The plots were left undisturbed for a period of one week. After one week, the top soil (3 cm depth) of the polluted plots were removed manually, homogenized and stockpiled. Precisely $10 \mathrm{~kg}$ of the composite soil sample was transferred into four $2 \times 2 \mathrm{ft}$ porous-bottomed wooden boxes. All planting boxes were watered consecutively for three days with surface water supplied from the sample area. The oil-treated soil and untreated soil (control) were left undisturbed for a period of one week before the application of nutrient supplements (remediation methods). The period of one week was expectedly enough for con- 
ditioning, necessary for the resurgence of biological activities in the test soil.

\subsubsection{Treatment with Nutrient Supplements}

The effect of the oil on the biological activities of soil was remedied with the application nutrient supplements as follows:

1) Contaminated soil $(10 \% \mathrm{v} / \mathrm{w})$ treated with $200 \mathrm{~g}$ of poultry manure;

2) Contaminated soil $(10 \% \mathrm{v} / \mathrm{w})$ with $200 \mathrm{~g}$ of NPK 15:15:15;

3) Contaminated soil ( $10 \% \mathrm{v} / \mathrm{w})$ without any treatment;

4) Uncontaminated soil without treatment (control soil).

All treatments except poultry manure was dissolved in distilled water and applied in liquid form to guarantee the uniform distribution within the soil medium. The nutrient application of $200 \mathrm{~g}$ was equivalent of $25 \mathrm{ton} / \mathrm{ha}$. These amount supplied 25,000 kg/ha of nitrogen for the 12 weeks remediation period. After nutrient application, the treated and untreated boxes were left undisturbed for four weeks, except for intermittent watering at an interval of two days. These treatments reduce the crude oil content in the contaminated soil from $50 \mathrm{~g} / \mathrm{kg}$ (unremedied soil) to 20.5 and 10.8 in NPK and poultry manure-treated soils respectively. Thereafter, the treated soils were separately covered with leguminous plants.

\subsubsection{Treatment with Leguminous Plants}

Three sets in triplicate experimental macrocosms were prepared, each for the three different species of legumesCalopogonium mucunoides, Centrosema pubescens and Pueraria phaseoloides. Four pre-treated seeds of each leguminous plant were examined to ascertain that they were similar in size before they were seeded into the wooden boxes. The plants were watered adequately on daily basis for 12 weeks to maintain a permanently wet environment and allowed to adapt and grow in vitro, forming buds and leaves before harvesting.

\subsection{Physicochemical and Biological Analysis of Test Soil, Plant and Microbial Biomass}

\subsubsection{Soil}

The wetland soil samples were analyzed prior to contamination with crude oil, after contamination and during the course of remediation using standard analytical methods. Prior to analysis, the soil samples were air dried and passed through a $2 \mathrm{~mm}$ sieve. Particle size distribution of the soil samples was analyzed by combination of wet sieving and hydrometer techniques [13] with calgon as the dispersing agent. The soil organic carbon content was determined by dichromate wet oxidation methods of Walkley and Black as modified by [14]. Total nitrogen was determined by Kjeldah digestion methods of [15]. Soil pH was determined in water using a PyeUnicam $\mathrm{pH}$ meter [16]. The hydrocarbon content in soils was analyzed by gas chromatography (HP5890) after extracting the soil samples with dichloromethane [17].

\subsubsection{Plant and Microbial Biomass}

Using a destructive approach, the legumes were harvested after every three weeks to examine the shoots and roots of the cultivated plants. On each sampling day, the shoots were carefully pooled out of the soil and the roots were manually separated from the soil and washed. The plant shoots and roots were dried at $70^{\circ} \mathrm{C}$ for 24 hours and then weighed and ground for determination of $\mathrm{N}$. The $\mathrm{N}$ concentration in plant shoots and roots was determined by digesting the ground plant samples using a micro-Kjeldahl procedure [18] and analyzed on a Technicon Autoanalyzer (Technicon Instruments Corporation, New York). The shoot N (total N accumulated in shoots) and root $\mathrm{N}$ (total $\mathrm{N}$ accumulated in roots) were calculated by multiplying the $\mathrm{N}$ concentration with the corresponding biomass of the shoots or roots, respectively. Mineral $\mathrm{N}\left(\mathrm{NH}_{4}-\mathrm{N}, \mathrm{NO}_{2}-\mathrm{N}\right.$ and $\left.\mathrm{NO}_{3}-\mathrm{N}\right)$ was determined by extracting soil samples with $2 \mathrm{MKCl}$ solution (soil:solution $=1: 5$ ) and analyzed on the Technicon Autoanalyzer. Soil microbial $\mathrm{N}$ was measured on $20 \mathrm{~g}$ soil samples using the fumigation-extraction technique [19] [20] and calculated by multiplying the flush of mineral $\mathrm{N}$ between the fumigated and unfumigated soil samples with a $\mathrm{K}_{\mathrm{n}}$ factor of 2.22 [21]. Soil microbial C was measured on $25 \mathrm{~g}$ oven-dry equivalent soil samples by the fumigation-incubation technique [22] and calculated by dividing the flush of $\mathrm{CO}_{2}^{-}$C by a $\mathrm{K}_{\mathrm{c}}$ factor of $0.411[23]$.

\subsubsection{Urease Assay}

Urease activity was measured following the procedure of [24]. A $20 \mathrm{~g}$ soil sample obtained from each box was 
dispensed into a polyethylene bottle and treated with $4 \mathrm{ml}$ of urea solution $\left(0.5 \mathrm{mmol} \cdot \mathrm{g}^{-1}\right.$ soil $)$. Soil samples were incubated at $37^{\circ} \mathrm{C}$ for $6 \mathrm{~h}$ with soil moisture contents at $60 \%$ of soil water-holding capacity. Therefore, hydrolysis of urea was inactivated by adding $100 \mathrm{ml} 1 \mathrm{M} \mathrm{KCl-phenyl} \mathrm{mercuric} \mathrm{acetate} \mathrm{(a} \mathrm{urease} \mathrm{inhibitor)} \mathrm{solution.}$ The suspension was shaken for $1 \mathrm{~h}$ and filtered through Whatman (No.1) filter paper. A suitable aliquot (5 ml) from the filtrate was analysed for urea. The amount of the hydrolyzed urea was calculated by the difference between the urea added initially and that left in the solution after incubation.

\subsection{Statistical Analysis of Data}

The variance of the data was analyzed using the GLM procedure of the SAS package [25]. Multiple comparisons were conducted using the Student-Newman-Keuls (SNK) procedure. The linear correlation and regression were conducted using the REG procedure.

\section{Results and Discussion}

The physicochemical properties of the test soil prior to contamination, after contamination and the remedied soils are presented in Table 1 . The un-contaminated soil, an acidic sandy loamy soil (ultisol) was characterized by $\mathrm{pH} 6.9$ and considerably high amount of available phosphorous, nitrogen and its related compounds (nitrate and ammonium). These attributes were slightly affected by simulation with crude oil. Conversely, there was increase in the amount of soil organic matter in the contaminated and remediedsoils than the uncontaminated soil. The $50 \mathrm{~g} \cdot \mathrm{kg}^{-1}$ of total petroleum hydrocarbon (TPH) obtained when crude oil was introduced into the soil was effectively reduced to $20.5 \mathrm{~g} \cdot \mathrm{kg}^{-1}$ in soil treated with NPK and $10.8 \mathrm{~g} \cdot \mathrm{kg}^{-1}$ in soil remedied with poultry manure. This implies that hydrocarbon can affect soil physical, chemical and biological properties including nitrogen cycling.

The amount of nitrogen $(\mathrm{N})$ in the test plants shoot and root were higher in cover crops grown in the uncontaminated soil than soils with different hydrocarbon content (Figure 1) suggesting that crude oil contamination reduced $\mathrm{N}$ uptake by plants. It has also been reported to influence water and nutrient uptake by plants, which is essential for plant growth [26]. The reduction in shoot and root $\mathrm{N}$ of the legumes grown on the crude oil contaminated soils observed in this study may be due to competition for available nutrients between the plants and microorganisms in soils [27]. However, the severity of the effect of oil contamination on $\mathrm{N}$ uptake and plant growth varies with the plant species and the original soil properties [28]. Our findings have revealed that the three plant species exhibited different responses to the hydrocarbon contents of the soil. For Pueraria phaseoloides, the shoot and root $\mathrm{N}$ of plants grown on uncontaminated soil, and those on contaminated soil remedied with poultry manure and NPK increased rapidly within the first 6 weeks. However, there was no significant difference in root $\mathrm{N}$ between poultry and NPK treated soils and the oil-contaminated soil (Figure 1). This indicates that $\mathrm{N}$ uptake by Pueraria phaseoloides was not affected by hydrocarbons within the range of $0.35-20.5 \mathrm{~g} \cdot \mathrm{kg}^{-1}$, although slight impact was noticed after 6 weeks of exposure. On the other hand, the shoot and root $\mathrm{N}$ contents

Table 1. Some properties of the treated and untreated soil samples.

\begin{tabular}{|c|c|c|c|c|}
\hline \multirow{2}{*}{ Properties } & \multirow{2}{*}{ Uncontaminated Soil } & \multirow{2}{*}{ Oil-Contaminated Soil } & \multicolumn{2}{|c|}{ Treated Soils } \\
\hline & & & Poultry Manure & NPK \\
\hline $\mathrm{TPH}\left(\mathrm{g} \cdot \mathrm{kg}^{-1}\right)$ & 0.35 & 50 & 10.8 & 20.5 \\
\hline SMC (\%) & 13 & 0.4 & 0.8 & 10 \\
\hline $\mathrm{SOM}\left(\mathrm{g} \cdot \mathrm{kg}^{-1}\right)$ & 46 & 50 & 60 & 56 \\
\hline Total N $\left(\mathrm{g} \cdot \mathrm{kg}^{-1}\right)$ & 5.3 & 5.0 & 4.5 & 4.8 \\
\hline $\mathrm{NH}_{4}^{+} \quad\left(\mathrm{mg} \cdot \mathrm{kg}^{-1}\right)$ & 6.8 & 3.6 & 1.8 & 2.4 \\
\hline $\mathrm{NO}_{3}^{-} \quad\left(\mathrm{mg} \cdot \mathrm{kg}^{-1}\right)$ & 16.5 & 2.8 & 12.4 & 10.8 \\
\hline Av. Phosphorous $\left(\mathrm{g} \cdot \mathrm{kg}^{-1}\right)$ & 6.4 & 5.8 & 4.6 & 5.2 \\
\hline $\mathrm{pH}$ & 6.9 & 6.7 & 6.8 & 6.8 \\
\hline
\end{tabular}

TPH represents total petroleum hydrocarbon. SMC represents soil moisture content. SOM represents soil organic matter. 

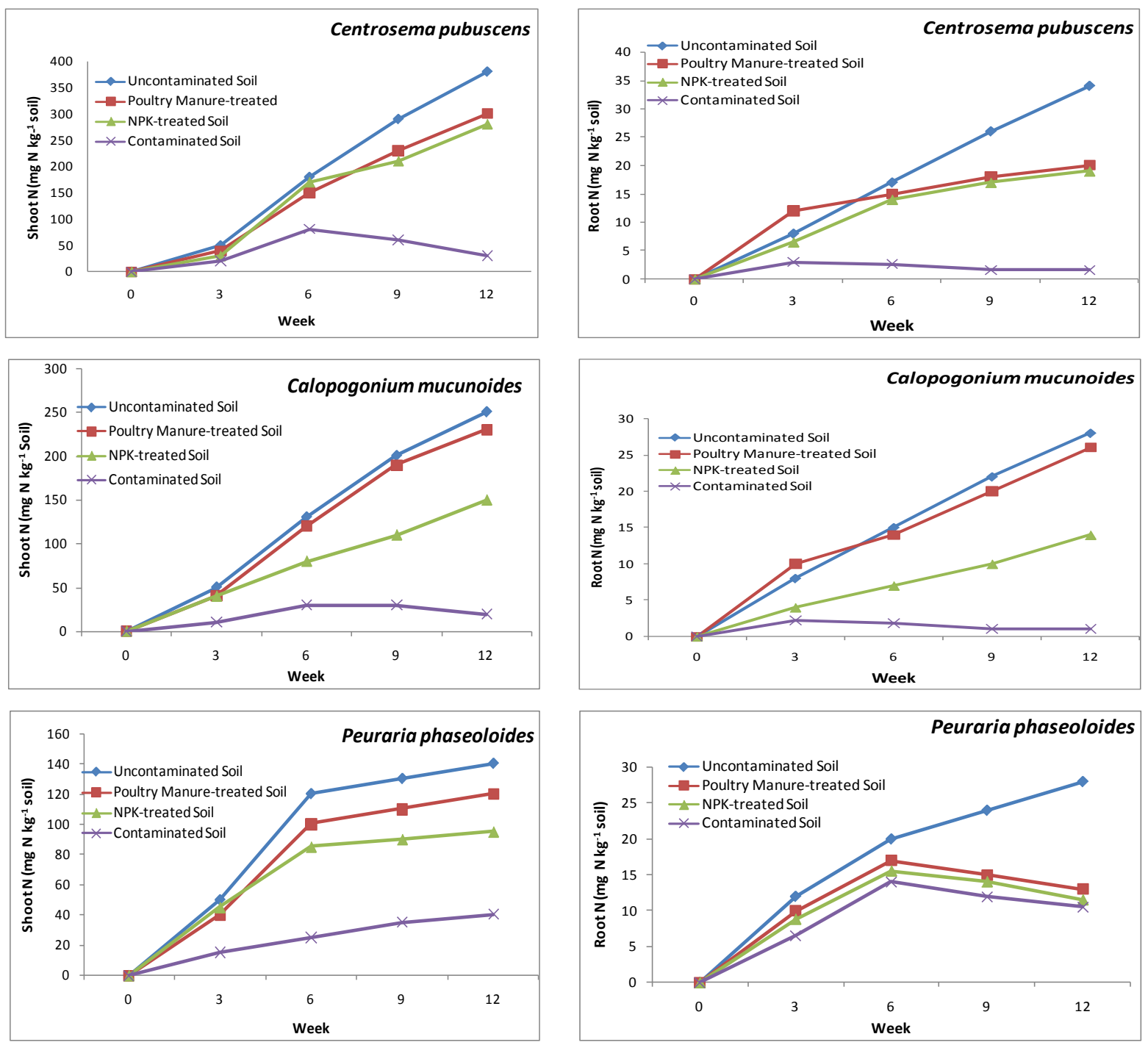

Figure 1. Shoot N and Root N during the growing period for Centrosema pubuscens, Calopogonium mucunoides and Pueraria phaseoloides grow in four soils with different hydrocarbon contents.

of Centrosema pubuscens and Calopogonium mucunoides were remarkably high in plants cultured on soils contaminated with crude oil levels higher than $20.5 \mathrm{~g} \cdot \mathrm{kg}^{-1}$. No significant difference was also recorded for shoot and root $\mathrm{N}$ levels of Centrosema pubuscens cultured on poultry manure and NPK remedied soils. Similarly, there was no remarkable difference in the shoot and root $\mathrm{N}$ levels of Calopogonium mucunoides grown on uncontaminated and poultry manure-treated soils. This indicates that the shoot and root N of Centrosema pubuscens and Calopogonium mucunoides were not severely impacted by hydrocarbons content within 0.35 - 50 $\mathrm{g} \cdot \mathrm{kg}^{-1}$ (Figure 1). The implication is that the shoot and root $\mathrm{N}$ of the legumes were more stable in Centrosema pubuscens followed by Calopogonium mucunoides than in Pueraria phaseoloide grown on soils with relatively higher levels hydrocarbon contamination. However, the root $\mathrm{N}$ of Pueraria phaseoloides also exhibited some level of stability among the cover crops cultured in soil with highlevel hydrocarbon contamination probably due to its bigger root mass. These findings indicate the potentials of these plants in reclamation of hydrocarbon contaminated soils. This potency may be ascribed to their capability to fix atmospheric $\mathrm{N}$ and establish a vegetative cover at a faster rate for crop plants.

The results have also shown that the microbial $\mathrm{N}$ increased while the mineral $\mathrm{N}$ decreased with increase in the level of hydrocarbons contamination (Table 2). This is suggestive that hydrocarbon contamination may cause available $\mathrm{N}$ to be immobilized into microbial biomass, thus reducing the availability of $\mathrm{N}$ for plant uptake. This 
Table 2. Mineral N, microbial C to microbial N ratio and mineral N in the four soils planted with centrosema, calopo and pueraria.

\begin{tabular}{|c|c|c|c|c|c|c|c|c|c|c|}
\hline \multirow{3}{*}{$\begin{array}{c}\text { Sampling } \\
\text { Periods }\end{array}$} & & \multicolumn{3}{|c|}{ Microbial N } & \multicolumn{3}{|c|}{ Microbial C/Microbial N } & \multicolumn{3}{|c|}{ Mineral N } \\
\hline & & Centro & Calopo & Pueraria & Centro & Calopo & Pueraria & Centro & Calopo & Pueraria \\
\hline & Soil Materials & \multicolumn{3}{|c|}{ (mg $\mathrm{N} \mathrm{kg}^{-1}$ soil) } & & & & \multicolumn{3}{|c|}{ (mg N kg ${ }^{-1}$ soil) } \\
\hline \multirow[t]{4}{*}{3 Weeks } & Uncontaminated soil & $16.6 \pm 2.2^{\mathrm{a}}$ & $15.8 \pm 2.5$ & $13.6 \pm 0.7$ & $7.2 \pm 0.4$ & $14.5 \pm 1.2$ & $16.4 \pm 1.5$ & $186 \pm 7.5$ & $174 \pm 3.4$ & $134 \pm 6.4$ \\
\hline & Oil-contaminated soil & $39.8 \pm 3.2$ & $39.1 \pm 2.4$ & $38.3 \pm 0.2$ & $20.8 \pm 0.8$ & $16.6 \pm 1.8$ & $12.7 \pm 2.2$ & $6 \pm 2.4$ & $3.8 \pm 1.8$ & $4.2 \pm 1.6$ \\
\hline & Poultry manure-treated soil & $29.7 \pm 2.8$ & $28.2 \pm 3.5$ & $18.2 \pm 0.6$ & $86.4 \pm 2.6$ & $75.2 \pm 1.6$ & $42.7 \pm 2.1$ & $168 \pm 2.8$ & $156 \pm 3.5$ & $131 \pm 7.6$ \\
\hline & NPK-treated soil & $18.2 \pm 2.5$ & $16.4 \pm 0.7$ & $12.5 \pm 0.4$ & $38.8 \pm 1.2$ & $30.6 \pm 1.5$ & $36.7 \pm 2.3$ & $134 \pm 2.8$ & $122 \pm 2.4$ & $118 \pm 3.6$ \\
\hline \multirow[t]{4}{*}{6 Weeks } & Uncontaminated soil & $7.2 \pm 0.6$ & $7.4 \pm 0.8$ & $7.8 \pm 0.6$ & $6.5 \pm 2.3$ & $24.5 \pm 1.6$ & $28.4 \pm 0.9$ & $156 \pm 6.4$ & $142 \pm 5.4$ & $24 \pm 2.1$ \\
\hline & Oil-contaminated soil & $38.2 \pm 0.8$ & $32.7 \pm 0.2$ & $26.2 \pm 0.4$ & $18.5 \pm 0.5$ & $15.3 \pm 0.7$ & $10.5 \pm 0.4$ & $4.2 \pm 0.5$ & $3.2 \pm 0.6$ & $2.2 \pm 1.2$ \\
\hline & Poultry manure-treated soil & $16.2 \pm 1.4$ & $14.6 \pm 0.8$ & $11.2 \pm 0.8$ & $86.4 \pm 2.5$ & $80.2 \pm 2.2$ & $68.4 \pm 2.9$ & $178 \pm 8.5$ & $156 \pm 2.8$ & $79 \pm 3.4$ \\
\hline & NPK-treated soil & $12.5 \pm 0.4$ & $10.4 \pm 0.5$ & $8.9 \pm 1.2$ & $84.6 \pm 1.7$ & $78.3 \pm 2.8$ & $32.1 \pm 1.1$ & $158 \pm 4.5$ & $137 \pm 3.5$ & $48 \pm 1.5$ \\
\hline \multirow[t]{4}{*}{9 Weeks } & Uncontaminated soil & $9.8 \pm 0.7$ & $6.6 \pm 0.8$ & $3.6 \pm 0.4$ & $4.6 \pm 0.8$ & $15.6 \pm 2.1$ & $19.4 \pm 1.2$ & $82 \pm 1.8$ & $66 \pm 2.8$ & $50 \pm 0.7$ \\
\hline & Oil-contaminated soil & $28.6 \pm 2.8$ & $28.0 \pm 2.1$ & $28.5 \pm 3.4$ & $14.7 \pm 0.6$ & $12.2 \pm 0.9$ & $8.3 \pm 0.7$ & $6.2 \pm 0.2$ & $5.4 \pm 1.8$ & $4.1 \pm 0.4$ \\
\hline & Poultry manure-treated soil & $16.5 \pm 2.6$ & $10.9 \pm 0.7$ & $9.8 \pm 1.4$ & $68.2 \pm 4.2$ & $76.5 \pm 2.6$ & $92.7 \pm 1.4$ & $182 \pm 5.6$ & $174 \pm 6.8$ & $13 \pm 1.4$ \\
\hline & NPK-treated soil & $15.4 \pm 1.5$ & $12.2 \pm 1.2$ & $4.8 \pm 1.5$ & $28.5 \pm 2.8$ & $22.3 \pm 1.2$ & $29.6 \pm 0.8$ & $162 \pm 2.6$ & $156 \pm 3.4$ & $7.5 \pm 2.6$ \\
\hline \multirow[t]{4}{*}{12 Weeks } & Uncontaminated soil & $5.2 \pm 0.4$ & $6.4 \pm 0.8$ & $7.6 \pm 1.5$ & $14.9 \pm 2.1$ & $10.6 \pm 0.3$ & $12.4 \pm 0.6$ & $16.5 \pm 0.6$ & $14.5 \pm 0.8$ & $11.1 \pm 0.4$ \\
\hline & Oil-contaminated soil & $30.6 \pm 2.1$ & $29.2 \pm 0.2$ & $28.6 \pm 2.4$ & $34.2 \pm 2.8$ & $30.6 \pm 1.3$ & $32.8 \pm 1.6$ & $2 \pm 0.8$ & $2 \pm 0.4$ & $2 \pm 0.6$ \\
\hline & Poultry manure-treated soil & $14.8 \pm 1.2$ & $14.3 \pm 0.7$ & $12.2 \pm 2.6$ & $98.6 \pm 7.7$ & $74.8 \pm 2.8$ & $56.4 \pm 2.4$ & $122 \pm 3.4$ & $110 \pm 5.6$ & $2.4 \pm 0.3$ \\
\hline & NPK-treated soil & $12.2 \pm 1.4$ & $10.8 \pm 0.4$ & $10.2 \pm 0.7$ & $50.4 \pm 2.6$ & $34.8 \pm 1.6$ & $26.7 \pm 1.3$ & $104 \pm 0.9$ & $101 \pm 0.2$ & $2.2 \pm 0.5$ \\
\hline
\end{tabular}

\begin{tabular}{|c|c|c|c|c|}
\hline \multirow{2}{*}{ Source of variance } & \multicolumn{3}{|c|}{ Summary of ANOVA } & \multirow{2}{*}{ Mineral N } \\
\hline & $\mathrm{DF}$ & Microbial N & Microbial C/Microbial N & \\
\hline Plant (P) & 2 & $* * \mathrm{~b}$ & NS & $* * *$ \\
\hline Soil (S) & 3 & *** & *** & *** \\
\hline Date (D) & 3 & * & * & $* * *$ \\
\hline $\mathrm{P} \times \mathrm{S}$ & 6 & NS & NS & * \\
\hline $\mathrm{P} \times \mathrm{D}$ & 6 & NS & * & ** \\
\hline $\mathrm{S} \times \mathrm{D}$ & 9 & * & NS & * \\
\hline $\mathrm{P} \times \mathrm{S} \times \mathrm{D}$ & 18 & * & NS & ** \\
\hline
\end{tabular}

${ }^{a}$ The numbers in the table are represented by mean \pm standard deviation (SD). ${ }^{b}$ The difference between means is significant at: $: \mathrm{P} \leq 0.05 ;{ }^{* * *} \mathrm{P} \leq 0.01 ;{ }^{* * * *} \mathrm{P} \leq 0.001$; NS, not significant.

is because once immobilized, $\mathrm{N}$ is re-mineralized slowly [29]. The microbial $\mathrm{N}$ of microorganisms in soil remedied with the test plants species was low in uncontaminated and treated soils over the growing period but very high in the oil-contaminated soil. This may be as a result of the sequestration of a large amount of $\mathrm{N}$ in the microbial biomass which may prevent losses of mineral $\mathrm{N}$ to the atmosphere and groundwater. This sequestered $\mathrm{N}$ can also be released slowly for recycling by microorganisms during the process of hydrocarbon degradation, or may be used for plant uptake. However, it was higher in soils remedied with Centrosema than Calopogonium which also had an edge over Pueraria (Table 2).

The ratio of microbial C: microbial $\mathrm{N}$ was highinpoultry manure-treated soil followed by the NPK-treated soil and then the oil-contaminated soil. Variation in the said ratio is due to the variable impact of hydrocarbons contamination levels and treatment approaches which influences the composition of microbial community since some microorganisms in soils are substrate-specific. The variation in levels of microbial $\mathrm{N}$ was similar to that of 
the microbial $\mathrm{C}$ and correlation between the microbial $\mathrm{N}$ and the total $\mathrm{C}$ (organic matter $\mathrm{C}+$ hydrocarbon $\mathrm{C}$ ) in soil was highly significant $(r=0.98, n=12, P \leq 0.01)$. However, the microbial $\mathrm{N}$ in soils covered with Centrosema was greater than in soils remedied with Calopogonium and Pueraria. Mineralization studies however showed a progressive decrease in ammonium- $\mathrm{N}$ levels and increase in nitrate levels in the uncontaminated soil overtime. This is indicative of nitrification process in soils that are free from contamination. This is confirmed by the strong negative correlation $(\mathrm{r}=-0.88, \mathrm{P} \leq 0.05)$ observed between the levels of nitrate- $\mathrm{N}$ and ammonium- $\mathrm{N}$ in the uncontaminated soil as against the strong positive correlation $(\mathrm{r}=0.96)$ between both parameters in treated (remedied) soils. Higher ammonium-N levels could indicate enhanced ammonification, reduced ammonium immobilization and reduced nitrification since these processes are intricately linked in soil and could influence the level of ammonium in soil [30].

Our results revealed that the plant species also had a significant effect on the mineral $\mathrm{N}$ content in soil. During the growing period, the mineral $\mathrm{N}$ in soil covered with Centrosema was greater than that of soils remedied with Calopogonium and Pueraria. It implies that more mineral $\mathrm{N}$ was taken up by Centrosema than Pueraria since the shoot $\mathrm{N}$ and root $\mathrm{N}$ of Centrosema were greater than those of Pueraria. In soils covered with Centrosema and treated with poultry manure and NPK the mineral $\mathrm{N}$ was greater than the values recorded for the uncontaminated soil and only decreased after 9 weeks of exposure (Table 2). Values recorded for the oil-contaminated soil was the least during the growing period. The differences in mineral $\mathrm{N}$ in the four soils at different sampling dates under the three plant species indicated that the interaction among the hydrocarbon content, plant growth stages and plant species was significant.

Biochemical reactions in soil, including transformation and cycling of plant nutrients, depend on the activities of different enzymes [31]. Urease activity deserves special attention since it plays a key role in transforming urea into ammonia for plant uptake [32]. The activity of soil urease correlated positively with the densities of microorganisms, organic matter content, total nitrogen and available phosphorous [33] [34]. In a similar study, soil urease activity showed a significantly negative correlation $(\mathrm{P}=0.001)$ with which could be used as the most sensitive indicator of petroleum contamination [35]. In this study, the urease activity was higher in soil remedied with Pueraria than Centrosema (Figure 2). This may be due to bigger root mass of Pueraria, since plant roots,

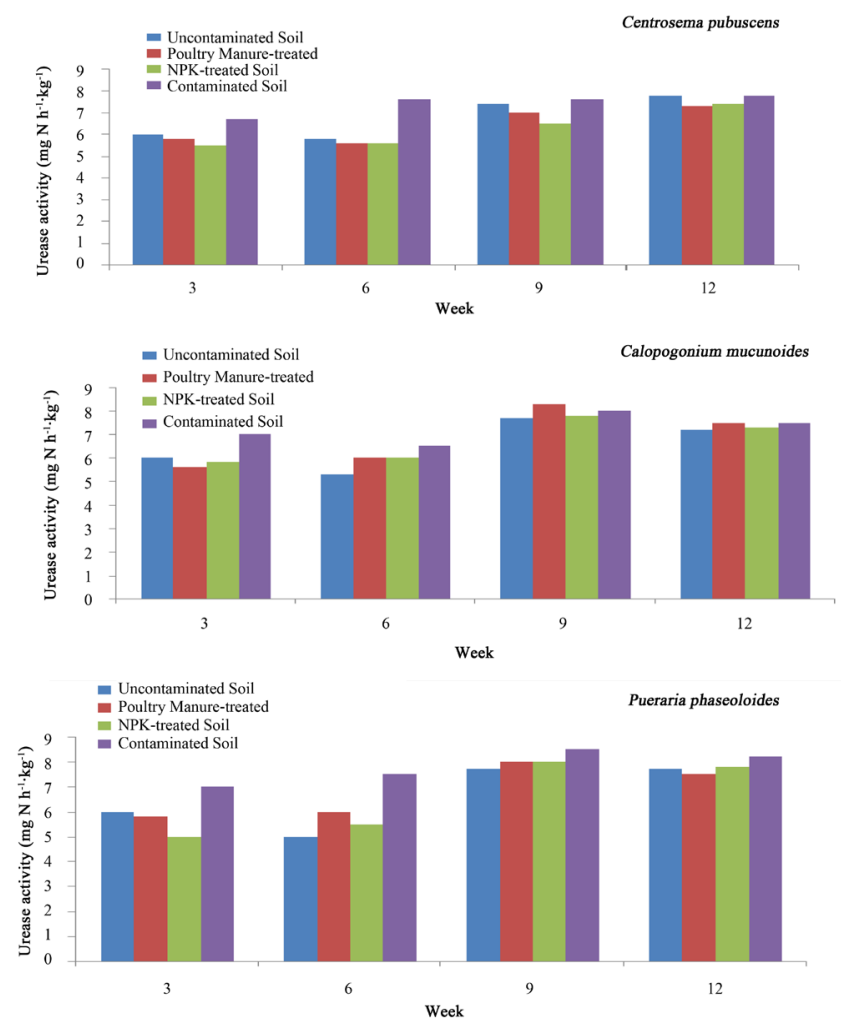

Figure 2. Urease activity in the four soils with different hydrocarbon content during the growing period under centrosema, calopogonium and pueraria. 
as well as microorganisms produce urease [36]. However, the urease activity in the oil-contaminated soil was higher than those in the control (uncontaminated) and nutrient supplemented soils, especially at the first two growth stages. This may be due to large microbial biomass (represented by microbial N) in the oil-contaminated soil. The influence of plant roots was also relatively less at the early growth stages. Similarly, the urease activities in the NPK and poultry manure-treated soils were lower than the rates obtained from the oil-contaminated soil. This indicates that both remediation methods reduce urea hydrolysis rate to enhance microbial degradation of hydrocarbons.

\section{Conclusion}

The study has demonstrated that hydrocarbon contamination widens the C:N ratios in soil. This leads to more available $\mathrm{N}$ to be immobilized by soil microorganisms and reduces $\mathrm{N}$ uptake by plants. The differences in the ratio of microbial $\mathrm{C}$ :microbial $\mathrm{N}$ among the four soil treatments are indicative of variation in microbial induced mineralization of hydrocarbons contaminants during the remediation processes. Both remediation methods reduced hydrocarbon content in the soil and had significant effects on $\mathrm{N}$ dynamics and cycling. Urease activity was very high in the oil-contaminated soil due to the elevated microbial biomass. Moreso, the higher urease activity recorded for Pueraria, may be associated with its bigger root mass. The findings show that $\mathrm{N}$ dynamics, transformation and cycling in soil are influenced by hydrocarbons and that the interactions between hydrocarbon content and plant species in contaminated soil are remarkable. The use of plant Centrosema pubescens with poultry manure or NPK fertilizer for bioremediation, is more effective than that of Calopogonium mucunoides and Pueraria phaseoloides. However, the selective attributes of the various treatment approaches adopted here may be exploited for enhanced remediation of contaminated wetlands in the Niger Delta region of Nigeria.

\section{References}

[1] Ladousse, A. and Tramier, B. (1991) Results of 12 Years of Research in Spilled Oil Bioremediation: INIPOL Eap 22. Proceedings of the 1991 Oil Spill Conference American Petroleum Institute, Vol. 1991, 577-581.

[2] Allen-King, R.M., Barker, J.F., Gillham, R.W. and Jensen, B.K. (1994) Substrate- and Nutrient-Toluene Biotransformation in Sandy Soil. Environmental Toxicology and Chemistry, 13, 693-705. http://dx.doi.org/10.1002/etc.5620130503

[3] Walworth, J.L and Reynolds, C.M. (1995) Bioremediation of a Petroleum-Contaminated Cryic Soil: Effects of Phosphorus, Nitrogen, and Temperature. Journal of Soil Contamination, 4, 299-310.

[4] Walworth, J.L., Woolard, C.R., Braddock, F. and Reynolds, M. (1997) Enhancement and Inhibition of Soil Petroleum Bioremediation through the Use of Fertilizer Nitrogen: An Approach to Determining Optimum Levels. Journal of Soil Contamination, 6, 465-480.

[5] Xu, J.G., Johnson, R.L., Yeung, P.Y. and Wang, Y. (1995) Nitrogen Transformations in Oil-Contaminated, Bioremediated, Solvent-Extracted and Uncontaminated Soils. Toxicological \& Environmental Chemistry, 47, 109-118. http://dx.doi.org/10.1080/02772249509358133

[6] John, R.C., Akpan, M.M., Essien, J.P. and Ikpe, D.I. (2010) Variation in Rhizosphere Microbiological Properties of Tropical Legumes Grown on Oil Contaminated Wetland Ultisol. Nigerian Journal of Microbiology, 24, 2081-2087.

[7] John, R.C., Akpan, M.M., Essien, J.P. and Ikpe, D.I. (2011) Fate of Nitrogen-Fixing Bacteria in Crude Oil Contaminated Wetland Ultisol. Bulletin of Environmental Contamination and Toxicology, 87, 343-353. http://dx.doi.org/10.1007/s00128-011-0320-1

[8] Amadi, A., Samuel, D.A. and Anthony, N. (1996) Chronic Effects of Oil Spill on Soil Properties and Microflora of a Rainforest Ecosystem in Nigeria. Water, Air, and Soil Pollution, 86, 1-11. http://dx.doi.org/10.1007/BF00279142

[9] John, R.C. (2007) Fate of Nitrogen-Fixing Bacteria in Crude Oil Contaminated Wetland Ultisol. Master's Degree Thesis, University of Uyo, Uyo, 211 p.

[10] Agboola, A.A. and Fayemi, A.A.A. (1972) Fixation and Excretion of Nitrogenby Tropical Legumes. Agronomy Journal, 64, 409-412. http://dx.doi.org/10.2134/agronj1972.00021962006400040001x

[11] Gadin, C. and Syratt, W.J. (1975) Biological Aspects of Land Rehabilitation. Environmental Pollution, 8, $107-112$. http://dx.doi.org/10.1016/0013-9327(75)90020-8

[12] Ile, O.P. (1997) Plant Nutrition for Sustainable Production and Environment. Kluwer Academic Publishers, Dordrecht, 751-752.

[13] Buurman, P., Van Langer, B. and Velthrost E.J. (1996) Manual for Soil and Water Analysis. Backhuys Publishers, Leiden. 
[14] Singh, D., Chhonkar, P.K. and Pandey, R.N. (1999) Soil, Plant \& Water Analysis-A Method Manual. IARI, New Delhi.

[15] Brady, N.C. and Weil, R.R. (1999) The Nature and Properties of Soils. 12th Edition, Prentice Hall Publishers, London, 1-9, 453-536, 727, 739-740.

[16] AOAC (2005) Methods of Soil Analysis. 12th Edition, Association of Official Analytical Chemists, Washington DC.

[17] US Environmental Protection Agency (1981) EPA Method 413.2 in Methods for Chemical Analysis of Water and Wastes. Environmental Monitoring and Support Laboratory, Cincinnati.

[18] Bremner, J.M. (1965) Total Nitrogen. In: Black, C.A., et al., Eds., Methods of Soil Analysis, Part II, American Society of Agronomy, Madison, 1171-1175.

[19] Vance, E.D., Brooks, P.C. and Jenkinson, D.S. (1987) An Extraction Method of Measuring Soil Microbial Biomass C. Soil Biology and Biochemistry, 19, 703-707. http://dx.doi.org/10.1016/0038-0717(87)90052-6

[20] Jenkinson, D.S. (1988) Determination of Microbial Biomass Carbon and Nitrogen in Soil. In: Wilson, J.B., Ed., Soil biochemistry, Marcel Dekker, New York, 415-471.

[21] Brookes, P.C., Landman, A., Pruden, G. and Jenkinson, D.S. (1985) Chloroform Fumigation and the Release of Soil Nitrogen: A Rapid Direct Extraction Method to Measure Microbial Biomass Nitrogen in Soil. Soil Biology and Biochemistry, 17, 837-842. http://dx.doi.org/10.1016/0038-0717(85)90144-0

[22] Jenkinson, D.S. and Powlson, D.S. (1976) The Effects of Biocidal Treatment on Metabolism in Soil. V. A. Method for Measuring Soil Biomass. Soil Biology and Biochemistry, 8, 209-213. http://dx.doi.org/10.1016/0038-0717(76)90005-5

[23] Anderson, J.E. and Domsch, K.H. (1978) Mineralization of Bacteria and Fungi in Chloroform Fumigated Soils. Soil Biology and Biochemistry, 10, 207-213. http://dx.doi.org/10.1016/0038-0717(78)90098-6

[24] Douglas, L.A. and Bremner, J.M. (1970) Extraction and Colorimetric Determination of Urea in Soils. Soil Science Society of America Journal, 34, 859-862. http://dx.doi.org/10.2136/sssaj1970.03615995003400060015x

[25] SAS Institute, Inc. (1987) SAS/STAT Guide. Version 6 Edition, SAS Institute, Inc., Cary.

[26] Baker, J.M. (1970) The Effects of Oils on Plants. Environmental Pollution, 1, 27-44. http://dx.doi.org/10.1016/0013-9327(70)90004-2

[27] Amadi, A., Dickson, A.A. and Maate, G.O. (1992) Remediation of Oil Polluted Soils: Effect of Organic and Inorganic Nutrient Supplements on the Performance of Maize (Zea mays L.). Water, Air, and Soil Pollution, 66, 59-76. http://dx.doi.org/10.1007/BF00477060

[28] John, R.C., Akpan M.M., Essien, J.P. and Ikpe, D.I. (2010) Impact of Crude Oil Pollution on the Densities of Nitrifying and Denitrifying Bacteria in the Rhizosphere of Tropical Legumes Grown on Wetland Soil. Nigerian Journal of Microbiology, 24, 2088-2094.

[29] Orji, J.C., Uzoho, B., Enwerem, J.O. and Ezurike, W. (2011) Assessment of the Impact to Kerosene and Diesel on Soil Nitrogen Mineralization. African Journal of Agricultural Research, 6, 2486-2493.

[30] Deenik, J. (2006) Nitrogen Mineralization Potential in Important Agricultural Soils of Hawaii. Soil and Crop Management, 16, 1-5.

[31] Xu, J.G., Heeraman, D. and Wang, Y. (1993) Fertilizer and Temperature Effects on Urea Hydrolysis in Undisturbed Soil. Biology and Fertility of Soils, 16, 63-65. http://dx.doi.org/10.1007/BF00336517

[32] Gianfreda, L., Sannino, F., Ortega, N. and Nannipieri, P. (1994) Activity of Free and Immobilized Ureasein Soil: Effects of Pesticides. Soil Biology and Biochemistry, 26, 777-784. http://dx.doi.org/10.1016/0038-0717(94)90273-9

[33] Chacon, N., Herrera, I., Flores, S. Gonzalez, J.A. and Nassar, J.M. (2009) Chemical, Physical, and Biochemical Soil Properties and Plant Roots as Affected by Native and Exotic Plants in Neotropical Aria Zones. Biology and Fertility of Soils, 45, 321-328. http://dx.doi.org/10.1007/s00374-008-0342-y

[34] Xue, D., Yao, H.Y. and Huang, C.Y. (2006) Microbial Biomass, N Mineralization and Nitrification, Enzymes Activities, and Microbial community Diversity in Tea Orchard Soils. Plant and Soil, 288, 319-331. http://dx.doi.org/10.1007/s11104-006-9123-2

[35] Li, H., Zhang, Y., Zhang, C.G. and Chen, G.X. (2005) Effect of Petroleum Containing Wastewater Irrigation on Bacterial Diversities and Enzymatic Activities in a Paddy Soil Irrigation Area. Journal of Environmental Quality, 34, 1073-1080. http://dx.doi.org/10.2134/jeq2004.0438

[36] Tabatabai, M.A. and Bremner, J.M. (1972) Assay of Urease Activity in Soils. American Journal of Soil Science Society, 41, 350-352. 